\title{
Passalora gochnatiicola sp. nov. on Gochnatia amplexifolia from Serra do Cipó, MG, Brazil
}

\author{
Olinto Liparini Pereira ${ }^{1,3}$, Robert Weingart Barreto ${ }^{1}$ and Uwe Braun ${ }^{2}$
}

Received: December 15, 2004. Acccepted: August 8, 2005.

\begin{abstract}
RESUMO - (Passalora gochnatiicola sp. nov. em Gochnatia amplexifolia da Serra do Cipó, MG, Brasil). O hifomiceto causador de mancha foliar Passalora gochnatiicola sp. nov., coletado em Gochnatia amplexifolia (Gardner) Cabrera (Asteraceae: Mutisieae) nos campos rupestres da Serra do Cipó (Minas Gerais, Brasil), é descrito, ilustrado, discutido e comparado com espécies afins.
\end{abstract}

Palavras-chave: Passalora gochnatiicola, espécie nova, hifomiceto cercosporóide

\begin{abstract}
Passalora gochnatiicola sp. nov. on Gochnatia amplexifolia from Serra do Cipó, Minas Gerais State, Brazil). The leafspotting hyphomycete Passalora gochnatiicola sp. nov., collected on Gochnatia amplexifolia (Gardner) Cabrera (Asteraceae: Mutisieae) in the 'campos rupestres' of Serra do Cipó (Minas Gerais State, Brazil), is described, illustrated, discussed and compared with allied species.
\end{abstract}

Key words: Passalora gochnatiicola, new species, cercosporoid hyphomycetes

\section{Introduction}

The 'Campos Rupestres' is a special vegetation type found in some Brazilian mountain regions, which is characterized by having unique geological and climatic conditions and a peculiar flora (Menezes \& Giulietti 2000). The 'Serra do Cipó' is a region located in the state of Minas Gerais, which is outstanding among other 'campos rupestres' in Brazil due to its high floristic diversity (Giulietti et al. 1987). In November 2000, botanists from the Universidade Federal de Viçosa collected in this region samples of the small shrub Gochnatia amplexifolia (Gardner) Cabrera (Asteraceae: Mutisieae) with lesions of a cercosporoid hyphomycete. The host plant is confined to this special vegetation type in the states of Bahia and Minas Gerais (Roque \& Pirani 1997). The leafspotting fungus on Gochnatia amplexifolia proved to be a new species of the genus Passalora Fr., which is described, illustrated and discussed in this paper.

\section{Materials and methods}

Small samples of the fungus were removed from fresh leaf spots and mounted in lactophenol. Observations, measurements and illustrations were carried out by means of an OLYMPUS BX 50 light microscope (Hamburg, Germany) fitted with a drawing tube.

\section{Taxonomy}

Passalora gochnatiicola O.L. Pereira \& U. Braun, sp. nov. MycoBank MB 500200.

Fig. 1-4

Etymology: from the host Gochnatia amplexifolia (Gardner) Cabrera (Asteraceae)

Differt a $P$. gnaphaliaceae conidiomatibus fasciculatis, sporodochialibus vel synnematibus, conidiophoris ad $250 \mu \mathrm{m}$ longis et conidiis 3-6 $\mu \mathrm{m}$ latis, 1-14-septatis.

\footnotetext{
1 Universidade Federal de Viçosa, Departamento de Fitopatologia, CEP 36571-000, Viçosa, MG, Brazil

2 Martin-Luther-University, Institute of Geobotany and Botanical Garden, Neuwerk 21, D-06099 Halle (Saale), Germany (braun@botanik.uni-halle.de)

3 Corresponding Author: liparini@bol.com.br
} 

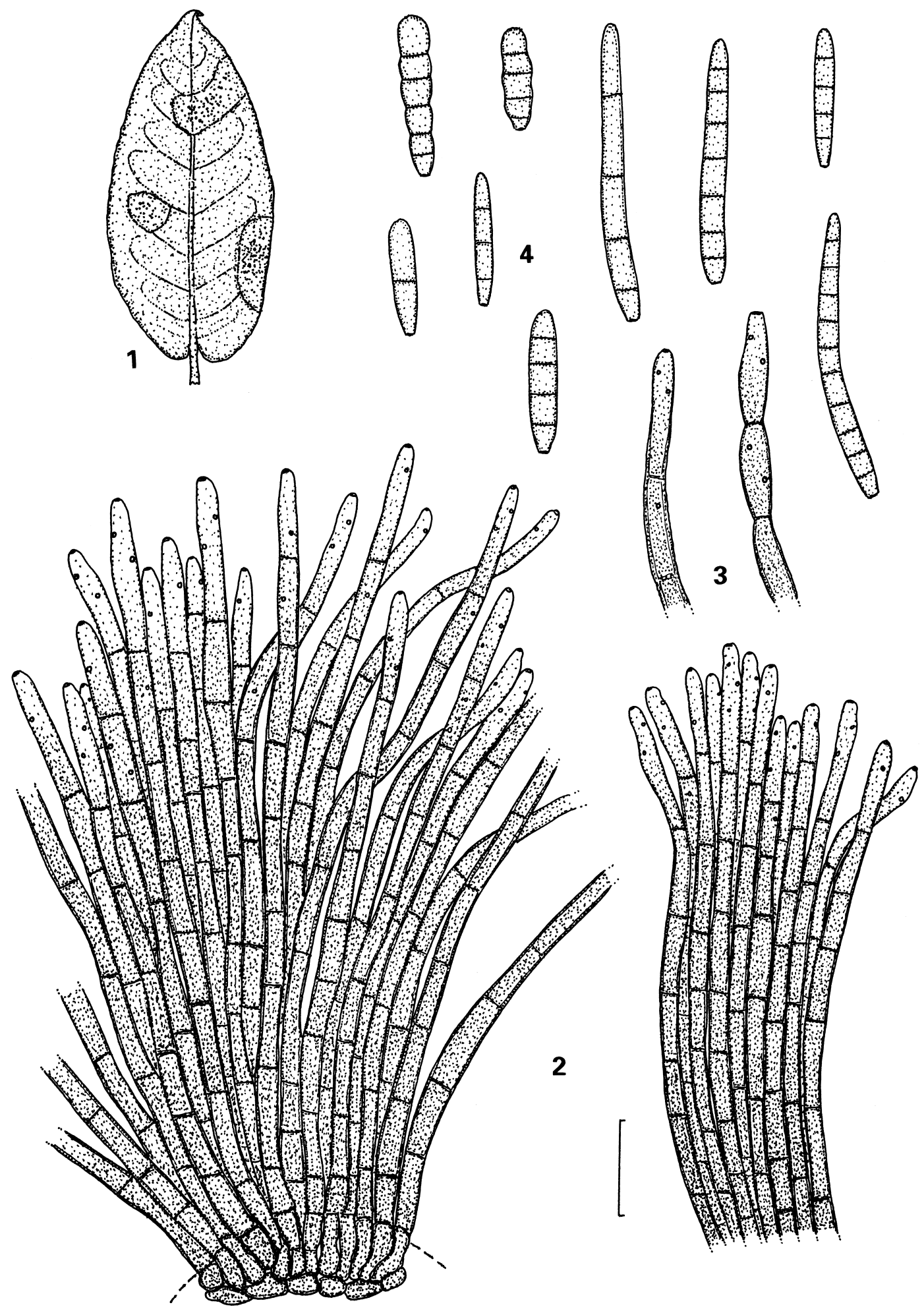

Figures 1-4. Passalora gochnatiicola O.L. Pereira \& U. Braun. 1. Leaf with symptoms (leaf spots). 2. Conidiomata. 3. Conidiophores with conidiogenous cells. 4. Conidia. Bar $(2-4)=20 \mu \mathrm{m}, 1$ (leaf) in original size. 
Holotype: BRAZIL. Minas Gerais: Serra do Cipó, Santana do Riacho, on leaves of Gochnatia amplexifolia (Gardner) Cabrera, 21/XI/2002, D.A.S. Oliveira (VIC 26535).

Isotype: BRAZIL. Minas Gerais: Serra do Cipó, Santana do Riacho, on leaves of Gochnatia amplexifolia (Gardner) Cabrera, 21/XI/2002, D.A.S. Oliveira, HAL 1797 (F).

Lesions on living leaves, amphigenous, but distinct leaf spots only formed on the upper leaf surface, at first elliptical to subcircular, later irregular, 9.0-20 mm diam., gray to dingy grayish white, margin narrow, purplish brown to blackish, leaf spots on the lower leaf surface almost absent, only visible as loose to dense aggregations of punctiform, dark brown to blackish conidiomata (Fig. 1). Internal mycelium, hyphae sparingly branched, septate, smooth, thinwalled, pale to medium brown, 2-5.5 $\mu \mathrm{m}$ wide. External mycelium lacking to sparsely developed, with some superficial hyphae, emerging through stomata (but consistently without any solitary conidiophores). Conidiomata amphigenous, punctiform to synnematous, dark brown, scattered to gregarious. Stromata absent to well-developed, substomatal to intraepidermal, up to $150 \mu \mathrm{m}$ diam., medium to dark brown, formed as loose to dense hyphal aggregations. Conidiophores in small, loose fascicles to very large, dense sporodochial conidiomata or synnemata (on the upper leaf surface usually in large, sporodochial conidiomata or synnemata; on the lower leaf surface often in fascicles or smaller, looser conidiomata), arising from internal hyphae or stromatic hyphal aggregations, emerging through stomata or erumpent, conidiophores long, filiform, barely or only slightly geniculate-sinuous, unbranched, 100-255×3-8 $\mu \mathrm{m}$, medium to dark brown, pluriseptate, occasionally constricted at the septa, wall thin or somewhat thickened, smooth to somewhat verruculose-rugose. Conidiogenous cells integrated, terminal or intercalary, subcylindrical, 10-35×3-6 $\mu \mathrm{m}$, sympodial, but nongeniculate, conidiogenous loci conspicuous, slightly thickened and darkened, 1-4 per conidiogenous cells, 1-2 $\mu \mathrm{m}$ wide, terminal and lateral, appressed against the wall of the conidiogenous cell, non-protruding (not at small shoulders since the conidiogenous cells are non-geniculate). Conidia solitary, obclavatecylindrical, 15-65×3-4 $\mu \mathrm{m}, 1-14-$ septate (septation variable, ranging from few, loosely arranged septa to densely pluriseptate), sometimes with constrictions at the septa, pale olivaceous to medium olivaceousbrown, thin-walled, smooth, apex obtuse, rounded, base rounded, subtruncate to short obconically truncate, hila unthickened to slightly thickened and slightly darkened-refractive, $1.5-2 \mu$ m wide.

\section{Discussion}

Passalora gochnatiicola is an unusual species characterized by having very variable conidiomata, ranging from loose fascicles to large, dense, sporodochial conidiomata and synnemata. The shape, size and septation of the conidia are also very variable. Relatively short conidia with numerous densely arranged septa are unusual for Passalora. However, based on the structure of the conidiogenous loci (slightly thickened and darkened-refractive) and conidia (obclavate-cylindrical, pigmented), this species has to be placed in Passalora. Passalora gochnatiicola is the first cercosporoid hyphomycete on a species of the genus Gochnatia. Comparable cercosporoid hyphomycetes are not known from potential host species of allied genera belonging to the Mutisieae (Crous \& Braun 2003). Most other species on hosts belonging to the Asteraceae are quite distinct from $P$. gochnatiicola either by having catenate conidia (Phaeoramularia type), e.g., $P$. helianthicola U. Braun \& Crous, P. plucheae (Petr. \& Cif.) U. Braun \& Crous and P. thitoniae (R.E.D. Baker \& W.T. Dale) U. Braun \& Crous (Chupp 1954; Ellis 1976; Crous \& Braun 2003), or by having superficial hyphae with solitary conidiophores (Mycovellosiella type), e.g., P. ambrosiae (Chupp) U. Braun \& Crous, P. mikaniae (F. Stevens) U. Braun \& F. Freire and P. perfoliati (Ellis \& Everh.) U. Braun \& Crous (Chupp 1954; Deighton 1974; Crous \& Braun 2003). Only a few species of Passalora on hosts of the Asteraceae with long conidiophores and solitary conidia are similar and comparable with $P$. gochnatiicola. The conidiophores of Passalora consimilis (Syd.) U. Braun \& Crous, on Vernonia spp. in Asia and South America, and P. umbrata (Ellis \& Holw.) U. Braun, on Bidens spp. in North America, are long, up to $200 \mu \mathrm{m}$, but they are consistently formed in relatively small, loose fascicles (Chupp 1954; Crous \& Braun 2003). Passalora gnaphaliaceae (Cooke) U. Braun \& Crous, on Gnaphalium spp. in Asia, North and South America, is close to $P$. gochnatiicola by having long conidiophores in well-developed synnemata and similar conidia, but fasciculate conidiophores and sporodochia are lacking and the conidia are 4-7 $\mu$ m wide and only 1-5-septate (Chupp 1954; Crous \& Braun 2003). 


\section{Aknowledgements}

We are grateful to Mr. Diego A.S. Oliveira (UFV Herbarium) for the identification of G. amplexifolia. O.L. Pereira and R.W. Barreto wish to acknowledge financial support from the CNPq (Conselho Nacional de Desenvolvimento Científico e Tecnológico).

\section{References}

Chupp, C. 1954. A monograph of the fungus genus Cercospora. New York, Published by the author.

Crous, P.W. \& Braun, U. 2003. Mycosphaerella and its anamorphs: 1. Names published in Cercospora and Passalora. Utrecht, CBS Biodiversity Series 1.
Deighton, F.C. 1974. Studies on Cercospora and allied genera V. Mycovellosiella Rangel, and a new species of Ramulariopsis. Mycological Papers 137: 1-75.

Ellis, M. 1976. More Dematiaceous Hyphomycetes. Kew, Commonwealth Mycological Institute.

Giulietii, A.M.; Pirani, J.R. \& Harley, R.M. 1987. Flora da Serra do Cipó, Minas Gerais: caracterização e lista das espécies. Boletim de Botânica da Universidade de São Paulo 9: 1-151.

Menezes, N.L. \& Giulietii, A.M. 2000. Campos Rupestres. Pp. 65-73. In: M.P. Mendonça \& L.V. Lins (eds.). Lista vermelha das espécies ameaçadas de extinção da flora de Minas Gerais. Brasil, Fundação Biodiversitas \& Fundação Zôo-Botânica de Belo Horizonte.

Roque, N. \& Pirani, J.R. 1997. Flora da Serra do Cipó, Minas Gerais: Compositae, Barnadesieae e Mutisieae. Boletim de Botânica da Universidade de São Paulo 16: 151-185. 